\title{
The Importance of Nature Based Mindfulness
}

\author{
Albrecht NJ*, Morgan B and Albrecht P \\ College of Education, Psychology \& Social Work, Australia
}

*Corresponding author: Albrecht NJ, College of Education, Psychology \& Social Work, Australia.

Received Date: October 21, 2019

Published Date: October 31, 2019

\section{Opinion}

The world in which we live, is crying out for humans to recognize the interdependence that exists between all life forms. Growing human consumption demands are playing a primary role in the demise of the environment, suggesting a disconnect between human society and its life support systems [1,2]. In order to reverse the ecological devastation humans have imposed on the planet a need to create change in our ways is evident [1]. The fields of Mindfulness and Sustainability Education are thought to be instrumental in helping more humans realize the importance of caring for and protecting our natural world [3].

Those working in these fields have seen an opportunity to further enhance humanity's connection with the environment and have created a range of nature-based mindfulness lessons and programs - lessons and programs that help individuals mindfully discover and develop a closer connection to the natural environment. In this opinion piece, we briefly outline the concept of nature-based mindfulness, give an example of a nature-based mindfulness activity, and discuss some critical skills needed to ensure that this deep connection people develop towards the natural world through nature-based mindfulness activities translates into pro-environmental action and behaviour.

\section{What is Nature-Based Mindfulness?}

Nature-based mindfulness is a term beginning to be used to describe activities and programs that connect the natural environment with mindfulness or other contemplative techniques. Nature-based mindfulness practices have a wide range of application.

They are used

- To cultivate a more mindful way of being and deepen a meditation practice [4].
- $\quad$ Develop the ecological self, including pro-environmental behaviours, such as mindful consumption $[5,6]$. The ecological self is perceived to be a wide, expansive or field-like sense of self, which ultimately includes all life-forms, ecosystems and the Earth [7].

- $\quad$ Help individuals cope with climate change [8], depression and stress $[9,10]$.

- $\quad$ Enhance wellbeing $[6,8,11,12]$.

- $\quad$ Enable a more creative, considered and holistic way of thinking, and approaching environmental problems $[3,8]$.

- $\quad$ Assist with equity issues

- $\quad$ To motivate social activism [8].

A wide variety of nature-based mindfulness activities have been designed to suit both children and adults. Snel, author of Sitting still like a frog: Mindfulness exercises for kids (2013) writes in relation to child-centric mindfulness that "the specific applications of this learning are seemingly boundless", and this sentiment seems to also apply to nature-based mindfulness (p. x). For example, in the book Into Nature: Mindful ways to unplug and reconnect [13], the authors offer 60 exercises to connect with nature - whether that be in the countryside, a park, an allotment, the garden, or on a balcony [13].

While there have recently been multiple practices designed to connect nature with mindfulness, scholars and teachers have been integrating mindfulness with nature for centuries [14]. A commonly used nature-based mindfulness practice that has been practiced for thousands of years is mindful walking. listen to (https://www. youtube.com/watch?v=NfPBIRE4RIc). Mindful walking is a key element in the majority of mindfulness-based programs for both children and adults $[15,16]$. In the practice of mindful walking in 
the natural world, students use their mind, body and senses to closely pay attention to the surrounding natural environment while gently walking. For example, in a woodland or park, attention can be directed towards the earth, trees, leaves, atmosphere, fauna, clouds, and/or temperature. If tuning into the earth the walker may ask of him or herself - "As I take each step, does the ground feel soft, hard, sticky, or uneven?", "How does my foot feel as I touch the earth?', 'Am I resting my heel on the ground first as I step or my toes?", "How does my connection with the earth feel through my whole body?" and so on. Teachers may remind students that our bodies and minds are embedded within the natural world, such that when we breathe in, we breathe in the out-breath of plants, shrubs, and trees [4]. And when we breathe out, we breathe out the in-breath of flowers, plants and trees [4].

When teaching nature-based mindfulness to undergraduate students we found that students develop or re-develop a closer connection and identification with the nature world, often reflecting and realizing their loss of connection to this world. However, we discovered that in most cases, this identification did not lead students to spontaneously care for their environment. We found that key to encouraging pro-environmental action and behavior was to provide students with some simple examples of how they could positively help their surrounding natural environment (Skills to Act) and specifically requested that they commit an environmental act of kindness (e.g., picking up rubbish in a local park) and report on this act in an assignment. All of the students when introduced to the concept of caring for the environment, engaged in various acts of kindness towards the natural environment and further uninitiated, the majority of the cohort brainstormed various ideas about future pro-environmental behavior and actions they could personally take. Requiring students to commit an environmental act of kindness became a crucial element in transforming the connection and identification students were feeling into caring for and protecting our natural world and is considered to be a critical facet when teaching nature-based mindfulness.

\section{Acknowledgement}

None

\section{Conflicts of Interest}

No conflicts of interest.

\section{References}

1. Edwards A (2015) The heart of sustainability. New Society Publishers, Gabriola Island, Canada.

2. Ericson T, Gunaketu Kjonstad B, Barstad A (2014) Mindfulness and sustainability. Ecological Economics 104: 73-79.

3. Eaton M, Davies K, Williams S, MacGregor J (2017) Why sustainability education needs pedagogies of reflection and contemplation. In: M Eaton, HJ Hughes, J MacGregor (Eds), Contemplative approaches to sustainability in higher education: Theory and practice, Taylor \& Francis Group, New York, pp. 3-15.

4. Van Gordon W, Shonin E, Richardson M (2018) Mindfulness and nature Mindfulness 9(5): 1655-1658.

5. Amel EL, Manning CM, Scott BA (2009) Mindfulness and sustainable behavior: Pondering attention and awareness as means for increasing green behavior. Ecopsychology 1(1): 14-25.

6. Geiger SM, Otto S, Schrader U (2018) Mindfully green and healthy: An indirect path from mindfulness to ecological behavior. Front Psychol 8: 2306.

7. Bragg EA (1996) Towards ecological self: Deep ecology meets constructionist self-theory. Journal of Environmental Psychology, 16(2): 93-108.

8. Wamsler C, Brossmann J, Hendersson H, Kristjansdottir R, McDonald C, et al. (2018) Mindfulness in sustainability science, practice, and teaching. Sustainability Science 13: 143-162.

9. Nisbet EK, Zelenski JM, Grandpierre Z (2019) Mindfulness in nature enhances connectedness and mood. Ecopsychology 11(2).

10. Schuling R, Van Herpen N, De Nooij R, De Groot WT, Speckens A (2018) Silent into nature: Factors enabling improvement in a mindful walking retreat in nature of people with psychological symptoms. Ecopsychology $10(2): 77-86$

11. Albrecht NJ (2016) Teachers teaching mindfulness with children: An interpretative phenomenological analysis (Doctoral Dissertation), Australia.

12. Kirwin M, Harper NJ, Young T, Itzvan I (2019) Mindful adventures: A pilot study of the outward-bound mindfulness program. Journal of Outdoor and Environmental Education 22(1): 75-90.

13. The Mindfulness Project (2019) Into Nature: Mindful ways to unplug and reconnect. Ebury Press, London.

14. Kaza S (2010) Mindfully green: A personal and spiritual guide to whole earth thinking. NSW: Finch Publishing, Warriewood, Australia.

15. Stahl B, Goldstein E (2010) A mindfulness-based stress reduction workbook. CA: New Harbinger Publications, Oakland, USA.

16. Snel E (2013) Sitting still like a frog: Mindfulness exercises for children (and their parents). MA: Shambhala, Boston, Massachusetts. 